\title{
Analisis Butir Soal Keterampilan Proses Sains Pada Instrumen Uji Coba Materi Ekosistem
}

\author{
Wianda Nurfauziah ${ }^{1}$, Sistiana Windyariani ${ }^{2}$ \\ Universitas Muhammadiyah Sukabumi ${ }^{1,2}$, \\ Wianda36@gmail.com ${ }^{1}$,windyariani@gmail.com²
}

\begin{abstract}
ABSTRAK
Penelitian ini bertujuan untuk mendeskripsikan kualitas butir soal keterampilan proses sains pada materi ekosistem. Jenis penelitian yang digunakan yaitu penelitian lapangan secara online melalui pendekatan deskriptif. Beberapa uji yang dilakukan di antaranya uji validitas, uji reliabilitas, uji tingkat kesukaran, dan daya pembeda. Penelitian ini dilaksanakan di SMA Negeri 4 Kota Sukabumi. Populasi dari penelitian ini yaitu siswa kelas XI IPA. Pengambilan sampel dalam penelitian ini dilakukan secara purposive sampling. Sampel dalam penelitian ini yaitu siswa kelas XI IPA 3 yang berjumlah 35 orang. Hasil analisis menunjukkan bahwa kualitas butir soal dari tingkat validitas soal, persentase soal valid sebesar $63 \%$ dan yang tidak valid sebesar 37\%. Hasil uji reliabilitas soal dengan menggunakan program AnatesV4 dan taraf signifikan 5\% dengan jumlah $\mathrm{N}=35$ diperoleh nilai $\mathbf{r}_{\text {tabel }}=0,334$, sedangkan $\mathbf{r}_{\text {hitung }}$ $=0,76$. Karena $r_{\text {hitung }} 0,76>r_{\text {tabel }}$ 0,334, maka Instrumen yang digunakan bersifat reliabel. Adapun tingkat kesukaran soal menunjukkan bahwa 70,3\% soal berada pada kategori sedang, dan 51,2\% memiliki daya pembeda dengan kategori baik atau sangat baik. Hasil analisis butir soal ini mengindikasikan bahwa soal keterampilan proses dikategorikan sudah valid dan reliabel serta dapat digunakan untuk penelitian selanjutnya.
\end{abstract}

Kata kunci: Daya Pembeda, Keterampilan Proses Sains, Uji Reliabilitas, Uji Validitas, Tingkat Kesukaran 


\begin{abstract}
ABSTARCT
This study aims to describe the quality of the item science process skills in the material ecosystem. This type of research is online field research through a descriptive approach. Some tests include validity, reliability, difficulty, and differentiation. This research was conducted at SMA Negeri 4 Sukabumi City. The population of this research is the students of class XI Science. Sampling in this study was conducted by purposive sampling. The sample in this study were 35 students of class XI Science 3. The analysis shows that the quality of the items from the level of validity of the questions, the percentage of valid questions was $63 \%$ and the invalid ones were $37 \%$. The reliability test results using the Anates V4 program and a significant level of 5\% with the number $N=35$ obtained rtable $=0.334$, while rcount $=0.76$. Because $r$ count 0.76> $r$ table 0.334, the instrument used is reliable. Then in terms of the level of difficulty, that at a percentage of $70.3 \%$ (29) the most difficult category is in the medium category. And in terms of distinguishing power, obtained a percentage of $51.2 \%$ which is a good or very good category relative to a very large percentage. In conclusion, questions that are valid and reliable can already be used for further research.
\end{abstract}

Keywords: Difficulty Level, Distinguishing Power, Reliability test, Science Process Skills. Validity Test.

\title{
PENDAHULUAN
}

Paradigma pembelajaran menurut kontruktivisme merujuk pada kontribusi peserta didik diharapkan untuk belajar berdasarkan pengalamannya secara langsung. Hal ini menuntut peserta didik untuk berinteraksi secara langsung dalam proses pembelajaran sehingga proses belajar mengajar menjadi aktif dan peserta didik lebih paham mengenai materi ajar yang disampaikan. Selain itu, proses pembelajaran harus dirancang dengan baik dan terstruktur sehingga dalam proses pembelajaran benar-benar harus terpusat kepada siswa (student centered learning) sebagai peserta didik dan guru bertindak sebagai fasilitator, pada akhirnya peserta didik benar-benar dapat mencapai tujuan yang diharapkan dalam proses pembelajaran tersebut.

Selain itu, Kurikulum 2013 menekankan kepada penguatan peserta didik dalam proses pembelajaran diharapkan untuk mencari tahu bukan hanya diberi tahu saja. Oleh karena itu pada tahapan-tahapan poses pembelajaran benar-benar harus diperhatikan dan ditekankan kepada peserta didik. Dalam pembelajaran sains bukan hanya menekankan kepada penguasaan-penguasaan produk saja, namun juga dalam penguasaan keterampilan proses ilmiah. Keterampilan proses dalam pembelajaran sains yang dikenal dengan keterampilan proses sains peserta didik.

Menurut Dahar (1996), keterampilan proses sains (KPS) merupakan kemampuan peserta didik untuk menerapkan metode ilmiah dalam memahami, mengembangkan dan menemukan ilmu pengetahuan. Selain itu, keterampilan proses sains yaitu keterampilan intelektual, sosial maupun fisik dapat diperlukan untuk memperoleh, mengembangkan, dan menerapkan dalam pengetahuan atau konsep yang telah dimiliki melalui pengalaman langsung (Nugraha, 2005; 
Rustaman, 2005; Trianto, 2008; Darwis dan Rustaman, 2015). Menurut Dahar (1985), keterampilan proses sains dapat melatih dan membantu peserta didik untuk menemukan konsep dan merupakan salah satu langkah penting dalam proses belajar mengajar khususnya dalam menemukan konsep materi IPA.

Sebagai bagian dari IPA, Biologi tidak terlepas dari hakikat dan karakteristik dalam IPA. Menurut Sumintono et al. (2010) Biologi juga terdiri dari dua bagian komponen dasar dalam IPA yakni Biologi sebagai produk dan proses. Menurut Sari (2013), faktanya dalam pembelajaran IPA di sekolah sangat cenderung hanya menghadirkan konsep, hukum-hukum dan teori saja, tanpa memberikan bagaimana proses yang ditemukan dalam konsep, hukumhukum dan teori tersebut sehingga dalam keterampilan proses sains dan sikap ilmiah yang dimiliki peserta didik tidak dapat tumbuh dalam diri peserta didik. Selain itu, dari hasil Trends in International Mathematics and Science Study (TIMSS) dan Program for International Student Assesment (PISA) menyatakan bahwa dalam pencapain anak-anak di Indonesia pada bidang IPA masih sangat rendah. Menurut data yang diperoleh dari TIMSS tahun 2015, Indonesia berada pada urutan ke-36 dari 49 negara dengan skor rata-rata sains 397 (TIMSS, 2016). Sementara itu, dari hasil PISA tahun 2015, Indonesia berada di peringkat ke-69 dari 76 negara dengan skor rata-rata IPA di Indonesia 403 (OECD, 2016). Berdasarkan paparan di atas, sangat terlihat bahwa dalam kemampuan bidang IPA peserta didik di Indonesia masih sangat rendah. Hal tersebut dapat dinyatakan bahwa peserta didik di Indonesia kebanyakan hanya menghafal konsep ilmu IPA tanpa peserta didik mengerti bagaimana dalam proses untuk memperoleh ilmu tesebut, sehingga dalam keterampilan proses sains peserta didik di Indonesia belum dapat dilatih dengan baik yang bermuara pada rendahnya kemampuan sains peserta didik.

Salah satu penyebab rendahnya keterampilan proses sains peserta didik merupakan pembelajaran disekolah yang cenderung berpusat pada guru (teacher-center learning), sehingga dalam proses pembelajaran yang lebih mendominasi oleh guru, sementara peserta didik kurang aktif dilibatkan dalam proses penemuan konsep (Fatimah, 2010). Dalam proses pembelajaran guru dapat cenderung hanya mengutamakan produk akhir sebagai satu-satunya aspek penilaian tanpa memperhatikan aspek lain seperti salah satu proses yang sesuai dengan hakikat IPA (Nurulita, 2012).

Selain itu, proses pembelajaran IPA apabila keterampilan proses sains tidak dilatih dan dikembangkan dengan baik, maka konsep dalam pengetahuan yang akan muncul tidak akan membantu pemahaman tentang dunia sekitar (Harlen, 1999). Selain itu, keterampilan proses sains yang dapat dilatih dalam pembelajaran IPA, diharapkan dapat membantu peserta didik dalam mencapai tujuan pembelajaran sesuai dengan KD yang telah ditentukan. Kemudian dalam pencapaian tujuan tersebut, peserta didik diharapkan dapat berperan aktif dalam proses pembelajaran. Salah satu penerapan pendekatan yang sesuai untuk melatih keterampilan proses sains peserta didik yaitu pendekatan saintifik (Marjan et al, 2014). 
Dalam rangka melatihkan proses sains, Rustaman (2003) menjelaskan bahwa keterampilan proses sains dapat dilatihkan dengan memberikan soal-soal keterampilan proses sains. Soal-soal tersebut disusun berdasarkan indikator keterampilan proses sains. Indikator keterampilan proses sains terdiri dari sebelas indikator yang meliputi mengamati, mengklasifikasi, interpretasi, prediksi, berkomunikasi, mengajukan pertanyaan, mengajukan hipotesis, melaksanakan percobaan, menggunakan alat dan bahan, dan menerapkan konsep. Keterampilan proses sains sangat penting dimiliki siswa untuk meningkatkan kemampuannya tidak hanya dari segi konsep, melainkan keterampilannya terutama dalam pembelajaran biologi. Dalam sebuah penelitian, ketika seorang peneliti ingin melatihkan suatu keterampilan kepada siswa, dibutuhkan rancangan yang diperlukan untuk proses pembelajaran yang disebut dengan instrumen.

Instrumen ini diperlukan untuk melatih siswa sesuai dengan indikator pencapaian. Dalam sebuah penelitian, instrumen merupakan alat yang sangat diperlukan oleh peneliti untuk mengukur sejauh mana siswa memahami dan menerapkan kemampuan yang dilatihkan. Seperti halnya untuk melatihkan keterampilan proses sains, peneliti membutuhkan instrumen yang baik untuk digunakan sebagai alat ukur dalam penelitiannya. Oleh karena itu, berdasarkan pemaparan di atas, peneliti bertujuan untuk menganalisis setiap butir soal yang menjadi instrumen dalam penelitian selanjutnya. Analisis ini diperlukan untuk mengetahui sejauh mana suatu Instrumen dapat digunakan dengan baik dalam penelitian. Jika hasil analisis Instrumen sudah baik, maka Instrumen dapat digunakan dalam penelitian untuk mengukur kemampuan keterampilan sains siswa tersebut.

\section{METODE PENELITIAN}

Jenis penelitian yang digunakan yaitu penelitian lapangan secara online melalui pendekatan deskriptif. Penelitian ini bertujuan untuk mendeskripsikan kualitas butir soal keterampilan proses sains pada materi ekosistem. Beberapa uji yang dilakukan di antaranya uji validitas, uji reliabilitas, uji tingkat kesukaran, dan daya pembeda. Penelitian ini dilaksanakan di SMA Negeri 4 Kota Sukabumi. Populasi dari penelitian ini yaitu siswa kelas XI IPA. Pengambilan sampel dalam penelitian ini dilakukan secara purposive sampling. Sampel dalam penelitian ini yaitu siswa kelas XI IPA 3 yang berjumlah 35 orang.

Instumen yang digunakan dalam penelitian ini yaitu soal tes keterampilan proses sains yang berjumlah 41 soal yang terdiri dari 10 indikator menurut Rustaman (2003) di antaranya mengamati, mengklasifikasi, interpretasi, prediksi, mengajukan pertanyaan, mengajukan hipotesis, merencanakan percobaan, menerapkan konsep, melakukan komunikasi, dan melaksanakan percobaan. Pengolahan data pada penelitian ini akan dilakukan melalui Anates V4 new.

Tahapan uji yang pertama dilakukan adalah uji Validitas soal. Uji validitas soal ini dilakukan untuk mengetahui sejauh mana soal tersebut dapat digunakan untuk penelitian. Uji validitas soal akan memverifikasi soal-soal yang sudah layak digunakan atau tidak layak 
digunakan. Hasil korelasi setiap butir soal kemudian akan dibandingkan dengan $r_{\text {tabel. }}$ Rumus yang digunakan dalam menentukan validitas soal adalah rumus korelasi Product Moment dengan angka kasar sebagai berikut:

$$
r X Y=\frac{\left(N \sum X Y\right)-\left(\sum X\right)\left(\sum Y\right)}{\sqrt{N \sum X 2-\left(\sum X\right) 2\left\{N \sum Y 2-\left(\sum Y\right) 2\right\}}}
$$

Keterangan:

$\mathrm{r}_{\mathrm{xy}}=$ koefisien korelasi product moment

$\mathrm{N}=$ Jumlah objek

$\mathrm{X}=$ skor butir soal

$\mathrm{Y}=$ Skor total

Hasil uji validitas kemudian akan diinterpretasikan sesuai dengan kategori yang mencakup kategori tinggi, cukup, atau rendah. Kemudian $r_{x y}$ akan dibandingkan dengan $r_{\text {tabel. }}$. Jika nilai $r_{x y}>r_{\text {tabel }}$ maka soal tersebut sudah valid. Namun apabila nilai $r_{x y}<r_{\text {tabel }}$, maka soal yang digunakan tidak valid. Tahap selanjutnya adalah tahap uji reliabilitas.

Uji reliabilitas digunakan untuk menentukan suatu data atau Instrumen memberikan hasil yang tetap dan tidak dapat berubah secara signifikan (Arikunto, 2010). Dalam penelitian ini data akan diintepretasikan sesuai dengan kriteria reliabilitas di bawah ini menurut Arikunto (2010):

Tabel 1. Kriteria nilai reliabilitas soal

\begin{tabular}{cc}
\hline Koefisien korelasi & Kriteria validitas \\
\hline $\mathbf{0 , 8 0 - 1 , 0 0}$ & Sangat tinggi \\
$\mathbf{0 , 6 0 - 0 , 7 9}$ & Tinggi \\
$\mathbf{0 , 4 0 - 0 , 5 9}$ & Cukup \\
\hline $\mathbf{0 , 2 0 - 0 , 3 9}$ & Rendah \\
\hline $\mathbf{0 , 0 0 - 0 , 1 9}$ & Sangat rendah \\
\hline$<0$ & Tidak Valid \\
\hline
\end{tabular}

Tahap selanjutnya adalah tahap tingkat kesukaran. Uji coba ini dilakukan untuk menentukan sejauh mana tingkat kesukaran suatu tes. Apabila tingkat kesukaran mencapai nilai tertinggi maka soal tidak dapat digunakan. Adapun kriteria nilai $\mathrm{P}$ yang diperoleh di kategorikan menurut Arikunto (2010) sebagai berikut:

Tabel 2. Kriteria Tingkat Kesukaran

\begin{tabular}{cc}
\hline $\mathbf{P}$ & Kriteria \\
\hline $\mathbf{0 , 0 0 - 0 , 2 9}$ & Sukar \\
$\mathbf{0 , 3 0 - 0 , 6 9}$ & Sedang \\
\hline $\mathbf{0 , 7 0 - 1 , 0 0}$ & Mudah \\
\hline
\end{tabular}


Tahap keempat adalah uji daya pembeda. Uji ini dilakukan untuk mengetahui siswa yang memiliki kemampuan tinggi dengan siswa yang memiliki kemampuan rendah. Daya pembeda akan ditentukan berdasarkan kriteria menurut Arikunto (2010) sebagai berikut:

Tabel 3. Kriteria Daya Pembeda

\begin{tabular}{cc}
\hline Indeks daya pembeda & Kriteria \\
\hline$<\mathbf{0}$ & Hubungan Negatif \\
\hline $\mathbf{0 , 0 0 - 0 , 2 0}$ & Jelek \\
\hline $\mathbf{0 , 2 1 - 0 , 4 0}$ & Cukup \\
\hline $\mathbf{0 , 4 1 - 0 , 7 1}$ & Baik \\
\hline
\end{tabular}

\section{HASIL DAN PEMBAHASAN}

\section{Uji Validitas}

Setelah dilakukan pengambilan data sebanyak 35 orang. Dilakukan interpretasi data dengan menggunakan kategori, dan menentukan nilai $r_{x y}$. Jika nilai $r_{x y}>r_{\text {tabel }}$ maka soal tersebut sudah valid. Namun apabila nilai $r_{x y}<r_{\text {tabel }}$, maka soal yang digunakan tidak valid. Berikut hasil uji validitas dari 41 butir soal yang sudah dilakukan.

Tabel 4. Hasil Uji Validitas Butir Soal

\begin{tabular}{ccc}
\hline Keterangan & Frekuensi & Persentase \\
\hline Valid & 26 & $63 \%$ \\
\hline Tidak Valid & 15 & $37 \%$ \\
\hline
\end{tabular}

Pada tabel 4, bahwa dari hasil 41 butir soal terdapat 63\% (26 soal) yang masuk dalam kategori valid, sedangkan 37\% (15 soal) memiliki kriteria tidak valid. Dari data tersebut dapat disimpulkan bahwa dari 41 soal, hanya 26 soal yang memiliki ketentuan yang sah dan dapat digunakan sebagai Instrumen penelitian, sedangkan 15 soal lainnya memiliki kriteria yang menyimpang dan tidak sesuai sehingga menghasilkan soal yang tidak valid. Berdasarkan penelitian yang dilakukan oleh Alpusari \& Hayati (2014) setiap butir soal yang masuk ke dalam kategori valid harus langsung dimasukan ke dalam soal penelitian dan digunakan untuk pengambilan data penelitian.

\section{Uji Reliabilitas}

Berdasarkan dari perhitungan realibilitas dengan menggunakan program AnatesV4 dan taraf signifikan 5\% dengan jumlah $\mathrm{N}=35$ diperoleh nilai $\mathbf{r}_{\text {tabel }}=0,334$, sedangkan $r_{\text {hitung }}$ $=0,76$. Karena $\mathbf{r}_{\text {hitung }} 0,76>\mathbf{r}_{\text {tabel }} 0,334$, maka Instrumen yang digunakan bersifat reliabel, artinya Instrumen tersebut sudah tetap dan tidak dapat berubah secara signifikan kembali. Hal ini di dukung oleh penelitian Ibrahim (2013), Nayla \& Ani (2012), yang menyatakan 
bahwa besarnya nilai reliabilitas dari hasil tes ujian yang terdiri dari 40 butir soal atau lebih akan relatif memiliki nilai reliabilitas yang tinggi, sehingga soal tersebut konsisten untuk digunakan sebagai alat ukur.

\section{Tingkat Kesukaran}

Berdasarkan perhitungan dari hasil tingkat kesukaran soal dapat dilihat pada tabel berikut ini:

Tabel 5. Tingkat Kesukaran

\begin{tabular}{cccc}
\hline $\begin{array}{c}\text { Tingkat } \\
\text { Kesukaran }(\mathbf{P})\end{array}$ & Kategori & Frekuensi & Persentase \% \\
\hline $\boldsymbol{< 0 , 2 5}$ & Sukar & 8 & 19,5 \\
\hline $\mathbf{0 , 2 5 - 0 , 7 5}$ & Sedang & 29 & 70,3 \\
\hline$>\mathbf{0 , 7 5}$ & Mudah & 4 & 9,7 \\
\hline
\end{tabular}

Pada tabel 5 dapat menunjukkan bahwa pada kategori sukar memperoleh persentase sebesar 19,5\% (8), pada kategori sedang 70,3\% (29) dan kategori mudah sebanyak 9,7\% (4). Dari data tersebut dapat dilihat bahwa kategori tingkat kesukaran paling banyak berada kategori sedang. Hal tersebut didasarkan pada fakta bahwa tidak semua siswa dapat menjawab soal yang diajukan, namun beberapa siswa juga dapat menjawabnya dengan baik. Pada kategori soal yang mudah, dapat diartikan bahwa siswa sebagian besar dapat menjawab pertanyaan tersebut dengan benar. Sedangkan pada kategori sukar, dapat diartikan bahwa sebagian besar siswa tidak dapat menjawab soal itu dengan baik. Hal ini sejalan dengan penelitian Ratnaningsih, (2012) menyatakan bahwa adanya kategori sukar pada soal mungkin disebabkan karena siswa tidak atau belum belajar dengan maksimal.

\section{Daya Pembeda Soal}

Berdasarkan hasil perhitungan daya pembeda soal dapat dilihat pada tabel berikut ini:

\section{Tabel 6. Kastegori Daya Pembeda}

\begin{tabular}{cccc}
\hline Daya Pembeda & Kategori & Frekuensi & Pesentase \% \\
\hline$<\mathbf{0}$ & Hubungan Negatif & 8 & 19,5 \\
\hline $\mathbf{0 , 0 0 - 0 , 2 0}$ & Jelek & 3 & 7,3 \\
\hline $\mathbf{0 , 2 1 - 0 , 4 0}$ & Cukup & 9 & 21,9 \\
\hline $\mathbf{0 , 4 1 - 0 , 7 1}$ & Baik & 21 & 51,2 \\
\hline
\end{tabular}

Pada tabel 6 dapat menunjukkan bahwa pada kategori hubungan negatif memperoleh persentase $19,5 \%$, pada kategori jelek memperoleh persentase 7,3\%, pada kategori cukup memperoleh persentase $21,9 \%$ dan kategori baik atau sangat baik memperoleh persentase $51,2 \%$. Dari data tersebut dapat dilihat bahwa kategori baik atau sangat baik relatif persentase yang sangat besar. Hal tersebut berarti bahwa soal-soal yang memiliki daya berbeda baik atau sangat baik dapay digunakan karena soal tersebut dapat membedakan antara siswa yang memiliki kemampuan tinggi, dengan siswa yang memiliki kemampuan rendah. Kemudian 
hal yang perlu diingat menurut Supandi \& Farikha (2015) yang menyatakan bahwa soal-soal itu tidak harus memiliki daya pembeda yang tinggi sehingga jika terdapat soal yang kategori cukup yang mnempounyai indeks deskriminasi 0,2 sampai 0,4 masih tetap boleh dipakai. Hasil penelitian ini didukung kuat oleh teori yang disampaikan Sudijono (2011) yang menyatakan bahwa menguji daya pembeda pada soal itu sangat penting sebagai dasar penyusunan butir soal agar dapat menentukan bahwa soal yang digunakan sudah baik.

\section{SIMPULAN}

Berdasarkan hasil analisis soal uji coba yang dilakukan dapat disimpulkan dalam kualitas butr soal keterampilan proses sains pada maeri ekosistem diantaranya: dari segi uji validitas, soal tersebut terdapat $63 \%$ (26) yang masuk dalam kategori valid, sedangkan $37 \%$ (15) memiliki kriteria tidak valid. Kemudian dari segi reliabilitas soal dengan menggunakan program AnatesV4 dan taraf signifikan 5\% dengan jumlah $\mathrm{N}=35$ diperoleh nilai $\mathrm{r}_{\text {tabel }}=$ 0,334 , sedangkan $r_{\text {hitung }}=0,76$. Karena $r_{\text {hitung }} 0,76>r_{\text {tabel }} 0,334$, maka Instrumen yang digunakan bersifat reliabel. Kemudian dari segi tingkat kesukaran, bahwa pada persentase $70,3 \%$ (29) yang kategori tingkat kesukaran paling banyak berada kategori sedang. Dan dari segi daya pembeda, memperoleh persentase 51,2\% yang kategori baik atau sangat baik relatif persentase yang sangat besar.

\section{DAFTAR PUSTAKA}

Alpusari, M. (2014). Analisis Butir Soal Konsep Dasar IPA 1 Melalui Penggunaan Program Komputer Anates Versi 4.0 For Windows. Jurnal Primary Program Studi Pendidikan Pendidik Sekolah Dasar Fakultas Kependidikan Dan Ilmu Pendidikan Universitas Riau, 4(1).2303-1514

Arikunto, S. (2010). Prosedur Penelitian Suatu Pendekatan Praktik. Jakarta: Rineka Cipta. Dahar, R.W. (1996). Teori-Teori Belajar. Jakarta: Erlangga.

Darwis, R. \& Rustaman, N. Y. (2015). Pembelajaran Berbasis Inkuiri dengan Aktivitas Laboratorium untuk Meningkatkan Keterampilan Proses Sains Peserta didik SMP. Jurnal Pendidikan IPA Indonesia, 4(1) 13-21.

Hadiat. (1994). Pendidikan Sains, Teknologi, dan Masyarakat di Indonesia. Bandung: Depdikbud.

Hayati, N. \& Djemari Mardapi. (2014). Pengembangan Butir Soal Matematika SD Di Kabupaten Lombok Timur Sebagai Upaya Dalam Pengadaan Bank Soa. Jurnal Kependidikan. 44(1).26-38

Ibrahim, M \& Aliata. (2013). Kualitas Tes Ujian Nasional Matematika Peserta didik SMP Negeri Di Kabupaten Button Utara Tahun Ajaran 2011-2012. Jurnal Penelitian Pendidikan Matematika. 1(1).

Nayla, A. A \& Ani Widayati. (2012). Analisi Butir Soal Tes Kendali Mutu Kelas XII SMA Mata Pelajaran Ekonomi Akutansi Di Kota Yogyakarta Tahun 2012. Jurnal Pendidikan Akuntansi Indonesia. 10(1) 1-6

Nugraha, A. (2005). Pengembangan Pembelajaran Sains Pada Anak Usia Dini. Jakarta: Depdiknas. 
Ratnaningsih, D,J \& Isfarudi. (2013). Analisis Butir Tes Objektif Ujian Akhir Semester Mahapeserta didik Universitas Terbuka Berdasarkan Teori Tes Modern. Jurnal Pendidikan Terbuka Dan Jarak Jauh, 14(2) 98-109.

Rustaman, A. (2005). Pengembangan Kompetensi (Pengetahuan, keterampilan, Sikap, dan Nilai) Melalui Kegiatan Praktikum Biologi. Penelitian Jurusan Pendidikan Biologi FPMIPA UPI Bandung.

Sari, P,M. (2013). Pengaruh Model Pembelajaran Berbasis Praktikum Terhadap Keterampilan Proses Sains, Sikap Ilmiah dan Penguasaan Konsep Sistem Regulasi (Tesis Diterbitkan). Bandung: Universitas Pendidikan Indonesia.

Sudijono, (2011). Pengantar Evaluasi Pendidikan. Jakarta : PT Rajagrafindo Persada.

Sumintono et al (2010). Pembelajaran Sains, Pengembangan Ketrampilan Sains Dan Sikap Ilmiah Dalam Meningkatkan Kompetensi Pendidik. Jurnal Al-Bidayah. 2(1) 63852.

Supandi \& Farikhah, L. (2015). Analisis Butir Soal Matematika Pada Instrumen Uji Coba Materi Segitiga.

Trianto. (2008). Model-model Pembelajaran Inovatif Berorientasi Konstruktivistik. (Konsep Landasan Teoritis-Praktis dan Implementasinya). Jakarta: Prestasi Pustaka Publisher. 